\title{
Effect of Treatment and Refrigeration on the Chemical and Microbiological Stability of Avocado (Persea
}

\author{
Americana) Spread \\ Kiin-Kabari, D. B. \& Hart A.D. \\ Department of Food Science and Technology \\ Rivers State University of Science and Technology \\ Nkpolu, Oroworukwo, P.M.B. 5080, Port Harcourt, Nigeria \\ E-mail: kabaridavid@yahoo.com
}

Received: July 25, 2012 Accepted: September 19, 2012 Published: December 1, 2012

doi:10.5296/jfs.v1i1.2144ＵRL: http://dx.doi.org/10.5296/jfs.v1i1.2144

\begin{abstract}
Avocado pear (Persea americana) was pulbed, blanched, mashed and treated with $3.3 \%$ salt, (sample B), a combination of salt and 7:5\% lime juice (sample C) and a control (Plain), as sample A. All three samples were stored under refrigeration temperature $\left(4^{\circ} \mathrm{C}\right)$ for a period of four days. Sensory evaluation conducted with sliced bread and biscuits showed that the spread treated with salt (Sample B) was preferred in terms of colour, texture, flavour and overall acceptability. All samples stored and evaluated daily showed sample A with a free fatty acid range of $1.65 \%-1.95 \%$ while sample B had a decreased free fatty acid from $1.53 \%$ on day 0 to $1.41 \%$ by the fourth day of storage, although, the difference between treatments were not significant $(\mathrm{P}>0.05)$ a minimal decomposition of fatty acid was observed. A significant reduction was observed in the peroxide formation in sample $\mathrm{C}$ with peroxide values ranging from $0.33 \mathrm{meg} / \mathrm{kg}$ on day 0 to $0.19 \mathrm{meg} / \mathrm{kg}$ by the fourth day. Other samples, $\mathrm{A}$ and $\mathrm{B}$ showed a gradual increase in peroxide formation during storage. Microbial count (cfu/g) was higher in sample A (control) with highest count of $8 \times 10^{7} \mathrm{cfu} / \mathrm{g}$ observed in day 2 . Samples treated with salt and lime juice (sample C) was more effective in the control of microorganisms with counts between $9 \times 10^{4} \mathrm{cfu} / \mathrm{g}$, and $3 \times 10^{5} \mathrm{cfu} / \mathrm{g}$ for days 0 and 4 respectively.
\end{abstract}

Keywords: Chemical stability, Microbiological stability, Avocado paste, Lime juice, Salt. 


\section{Introduction}

Avocado pear (Persea americana) is both tropical and subtropical edible fruits, it is known to have originated from Central America and can now be found in three horticultural races of West India, Central and East Central Mexico and Guatemala (Morton, 1987). In Nigeria, Avocado pear is available, however, it is seasonal and highly perishable. Avocado pear has some advantages in view of its nutritional composition. It is known to contain linoleic acid, a polyunsaturated fatty acid which is highly digestible and reduces blood cholesterol level and decreases the incidence of heart diseases when compared to animal fats (George et al 1998, and Bergh, 1990b). Its protein is low and does not produce waste such as uric acid which tends to acidify the body on consumption. The pear fibre is also known to prevent gastro-intestinal diseases in human (Bergh, 1990a).

Avocado pear is considered a nutrient dense food with vitamins such as thiamin, Riboflavin, Niacin, Panthenic acid, total and free folic acid, tocopherol (Rainey et al 1994). It is known to contain minerals such as calcium, potassium, iron, and magnesium (Aryadasa, 2000). In Nigeria, the pear is consumed by all categories of people either as a fruit or desert. It can be mashed easily and has a bland taste which makes a good source for weaning food (Ihekoronye and Ngoddy 1985).

Due to the nutritional quality of the pear in relation to human health, this study is aimed at investigating the effects of treatment such as addition of salt and limejuice on the free fatty acid and peroxide value of the spread and also to determine the microbial stability of the spread during storage.

\section{Materials and Methods}

Avocado pears, common salt and lime were purchased from Mile I market in Port Harcourt, Nigeria. Fresh, wholesome ripe fruits of the same species were used.

\section{Preparation of Avocado Pear Spread}

40 Avocado pear fruits were cut longitudinally and their seeds removed. The pulp was scooped out using a clean dessert spoon and steam blanched at $80^{\circ} \mathrm{C}$ for 10 minutes. It was carefully mashed to a smooth and fine paste.

The spread was divided into three portions A, B and C. 3.3\% common salt was added to sample B while sample C contain 7.6\% limejuice and 3.3\% common salt. Sample A served as control. All samples were mixed thoroughly and packaged in plastic containers with cover and stored as reported by Hart et al, (2006).

\section{Storage and Shelf Life Studies}

The packaged samples were stored at refrigeration temperature of $4^{\circ} \mathrm{C}$ for four days.

Sample were analysed daily for free fatty acid (FFA \%), peroxide value using the method of Harold et al (1981).

Microbiological Analysis of Spread 
Microbiological analysis was also determined daily. Nutrient Agar (Oxoid) obtained from Aldrich chemical company inc. U.S.A was used and $0.9 \%$ sodium chloride was used as diluents. Total viable count was determined on the Avocado spread using the method of Harrigan and McCane (1990). Plates showing between 30 to 300 colonies were counted (Anon, 1994) and expressed as colony forming unit per gram (cfu/g).

\section{Sensory Evaluation}

The sensory, evaluation of the avocado spread (A, B and C) was determined by a panel of 20 members (Semi-trained), using a nine point hedonic scale. The panelist rated the product (spread)eaten with a slice of bread or biscuits with reference to colour, flavour, texture, spreadability and general acceptability.

The results obtained were then subjected to statistical analysis (Wahwua, 1999). ANOVA table was used to determine the significant difference between the sample means and least significant difference (LSD) was used to determine the difference between treatment means.

\section{Results and Discussion}

Sample A (plain) showed an increasing free fatty acid formation from $1.65 \%$ for day 0 to $1.95 \%$ by the fourth. The effects of salt on the Avocado spread in treatment B showed a decreasing effect from initial free fatty acid of $1.53 \%$ to $1.41 \%$ by day four. Sample C showed a fluctuating effect, this might be due to the effects of limejuice on the spread. In spite of the variations in the free fatty acid (\%) between the treatment methods, the result agreed with the work done by Harold et al (1981) who reported a free fatty acid range of 0.5 $2.0 \%$ to indicate good oils. The results showed that minimal decomposition of the fatty acids had taken place during the four days of storage as indicated in Figure 1, and that fatty acid decomposition may not contribute to spoilage of the spread. Figure 2 shows the peroxide value $(\mathrm{Meg} / \mathrm{kg})$ monitored for 4 days. Peroxide value ranged from $0.40 \mathrm{meq} / \mathrm{kg}$ to 0.62 $\mathrm{meq} / \mathrm{kg}$ for sample A. Comparatively, at day 0, all samples A, B and C were not significantly different $(\mathrm{P}>0.05)$. The increasing trend with storage observable in sample A (plain avocado spread) could be due to oxidation leading to the formation of peroxides.

Sample C had the lowest peroxide formation with a decreasing effect from $0.33 \mathrm{meg} / \mathrm{kg}$ for day 0 to $0.19 \mathrm{meg} / \mathrm{kg}$ by the fourth day of storage. This decreasing trend showed that common salt (3.3\%) with limejuice (7.6\%) in a synergism provided antioxidant activity on Avocado spread during the period of storage. It was observed that sample A had the highest microbial count increasing to $8 \times 10^{7} \mathrm{cfu} / \mathrm{g}$ recorded on day 2 and decreased to $6 \times 10^{7} \mathrm{cfu} / \mathrm{g}$ on the $4^{\text {th }}$ day. Sample B increased from $7 \times 10^{4} \mathrm{cfu} / \mathrm{g}$ on day 0 to $3 \times 10^{6} \mathrm{cfu} / \mathrm{g}$ by day 2 and further decreased to $4 \times 10^{5} \mathrm{cfu} / \mathrm{g}$ by the fourth day of storage as shown in Figure 3. This decrease may be attributed to osmotic dehydration due to salt on microorganism or the production of toxic metabolites. This also agreed with the observation of Sachindra and Sripathy (1991) who reported that a decrease in bacterial load with the addition of salt. Common salt in this case showed both bacteriostatic and bacteriocidal effects.

Sample C (lime + salt), showed the least increase in microbial load, with an initial load of $9 \mathrm{x}$ $10^{4} \mathrm{cfu} / \mathrm{g}$ to $3 \times 10^{5} \mathrm{cfu} / \mathrm{g}$ by the fourth day of storage. This may be due to the synergistic action 
of lime and salt, which provided both the acidic (Susan and Anne, 1998) and hydro osmotic conditions that prevent the growth of microorganisms.

Figure 4 showed that sample B was preferred in terms of colour, flavour, texture and the overall acceptability.

\section{Conclusion}

Avocado spread with $3.3 \%$ salt (sample B) provides a better sensory property in relation to colour, flavour, texture and overall acceptability. However, addition of $7.6 \%$ limejuice and $3.3 \%$ salt to the spread (sample C) provides a more microbiologically stable product. Sample $\mathrm{C}$ also prevents oxidative rancidity during the four days of refrigerated storage. Therefore, sample B was chemically more stable while sample C was microbiologically more stable during the storage periods, at refrigerated temperature. Further works should be done on the effect of packaging materials on shelf-stability of the paste.

\section{References}

Aryadasa R. (2000). The most nutrition Firsts Daily News pp. 5-7.

Bergh, B. (1990). The Avocado and Human Nutrition II. Some Human Health aspect of Avocado. In Proceedings of the 2nd World Avocado Congress, 1, 37-47.Los Angeles.

Bergh, B. (1990a). The Avocado and Human Nutrition II. Avocado and Your Health; In Proceedings of the 2nd World Avocado Congress, 1, 25-35. Los Angeles.

George, D., \& Pamplonia Roger M.O. (1998). Education and Health Library. Encyclopedia of Medical plants II. 1st ed.

Harold E, Kirk, R. S., \& Sawyer, A. (1981). Parson's Chemical Analysis of Foods. 8th Edition, Churchill Livingstone, London.

Harrigan, W. F., \& McCane, M. E. (1990). Laboratory Methods in Food and Dairy Microbiology. Academic Press, London.

Hart, A.D, Barimalaa I. S., \& Kiin-Kabari D.B. (2006), Utilization of the Nigerian Pear (Dacryodes edulis) as a spread. Nigerian Food Journal, 24(1), 114-117. http://dx.doi.org/10.4314/nifoj.v24i1.33641

Ihekoronye, A. I., \& Ngoddy, P. O. (1985). Integrated Food Science and Technology for the Tropics. Macmillan Pub. Ltd. London.

Morton, J. F. (1987). Avocado. In Fruits of Warm Climate. Miami F. L. pp. 91 - 102.

Rainey, C., Affick, M., Bretschger, K., \& Alfin Slaster, R. B. (1994). The California Avocado. Nutrition Today 29 93, pp. 232 - 27.

Sachindra, N. M., \& Sripathy, N. V. (1991). Bacterial Profiles of Salted, Sun dried Mackerel, changes during processing and storage. Indian Journal of Microbiology. pp. 191 - 196. 


\section{Macrothink}

Journal of Food Studies ISSN 2166-1073 2012, Vol. 1, No. 1

Susan, M., \& Anne (1998). Tropical and Sub-tropical Foods, 178-181. Macmillan Pub. Ltd. London.

Wahwua, T. A. T. (1991). Applied Statistics for Scientific Studies, 137-143Africa Links Books, U. I.

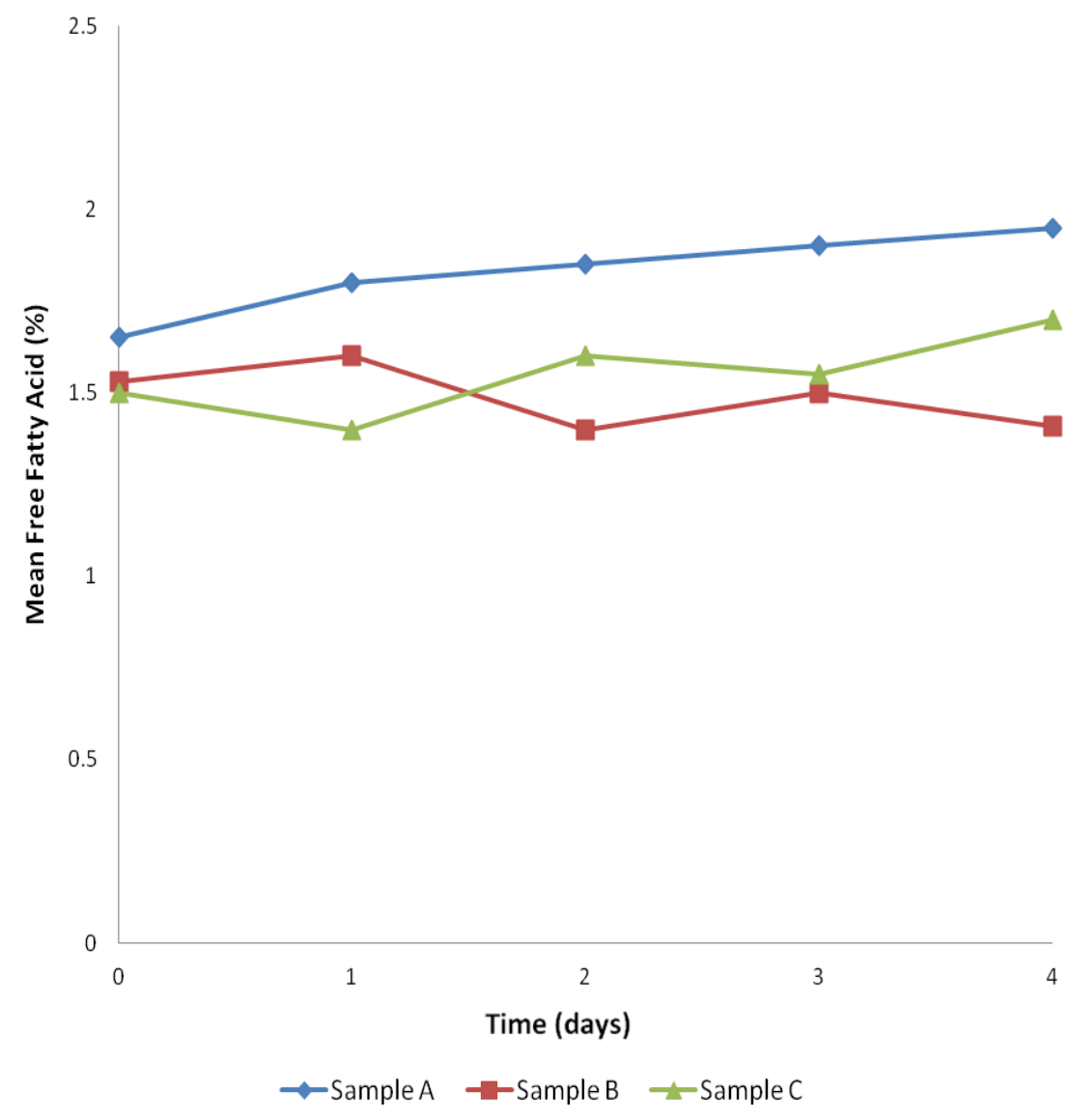

Figure 1. Mean free fatty acid of Avocado spread

Key:

A - Plain Avocado Spread(control)

B - Avocado spread with 3.3\% salt

C - Avocado spread with 3.3\% salt and 7.6\% lime 


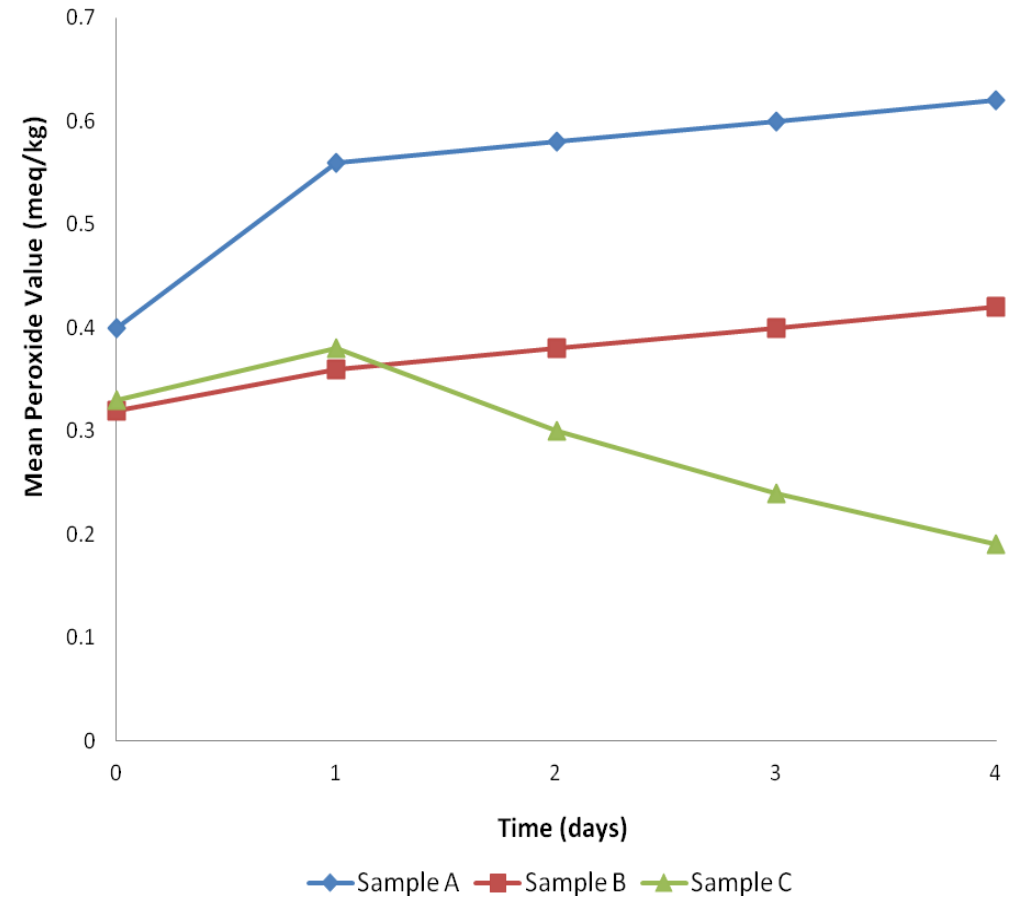

Figure 2. Mean peroxide value of Avocado spread

Key:

A - Plain Avocado Spread(control)

B - Avocado spread with 3.3\% salt

C - Avocado spread with 3.3\% salt and 7.6\% lime

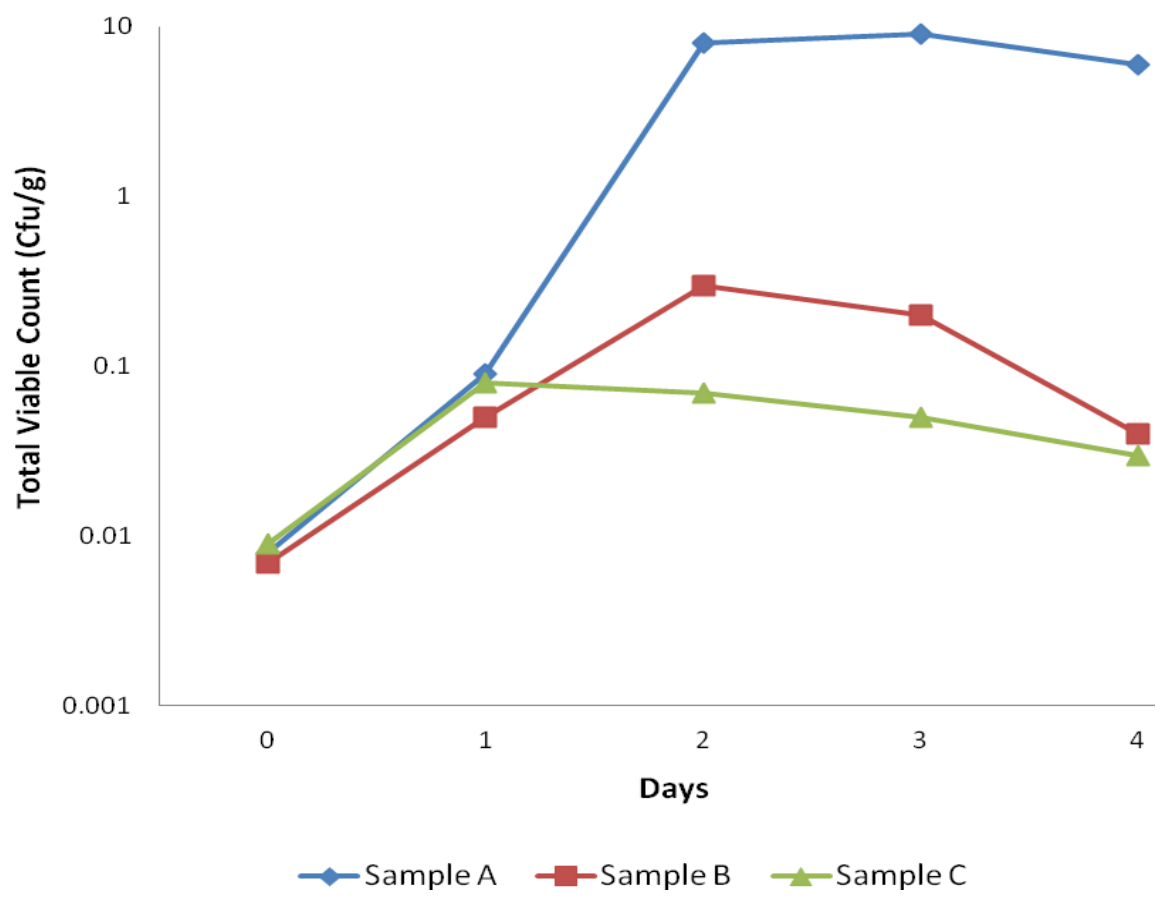


Figure 3. Total Viable Count (cfu/g) during storage

Key:

A - Plain Avocado Spread(control)

B - Avocado spread with 3.3\% salt

C - Avocado spread with 3.3\% salt and 7.6\% lime

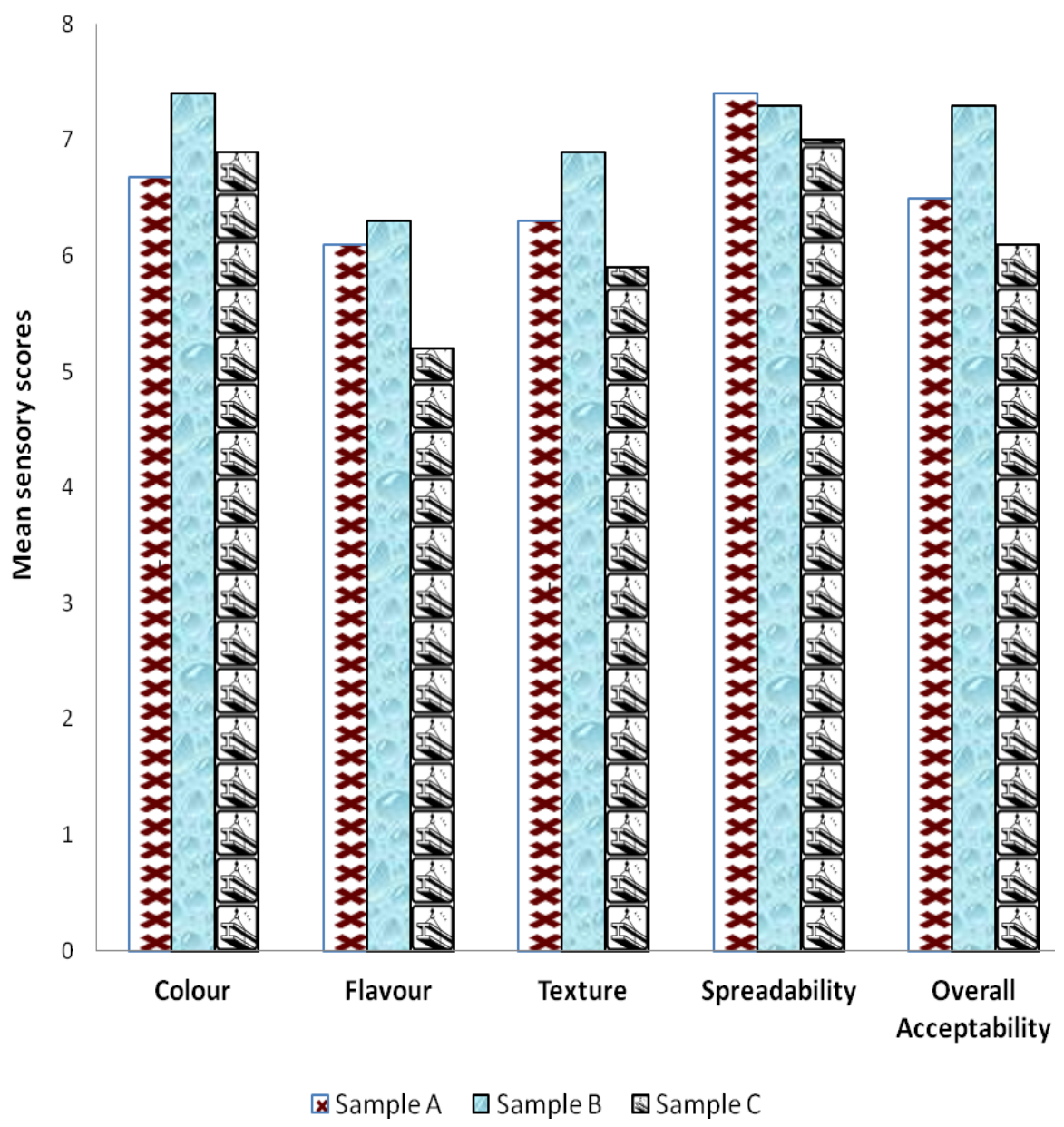

Figure 4. Mean Sensory Scores Evaluation

Key:

A - Plain Avocado Spread(control)

B - Avocado spread with 3.3\% salt

C - Avocado spread with 3.3\% salt and 7.6\% lime 